\title{
Special Issue Submission
}

Sport and Neoliberalism:

An Affective-Ideological Articulation

David L. Andrews/ University of Maryland Michael L. Silk/ Bournemouth University, UK 


\section{Introduction: Neoliberal Structures of Sporting Feeling}

Imagine if the people of the Soviet Union had never heard of communism. The ideology that dominates our lives has, for most of us, no name. Mention it in conversation and you'll be rewarded with a shrug. Even if your listeners have heard the term before, they will struggle to define it. Neoliberalism: do you know what it is? (Monbiot)

How is it possible that Monbiot (Monbiot) can write so convincingly about the seeming imperceptibility of a phenomenon that has also been described as a "planetary vulgate” (Bourdieu and Wacquant)? The answer to this question speaks to the very nature of neoliberalism itself. In the broadest terms, neoliberalism is an amorphous, complex, and oftentimes contradictory formation encompassing the new economic rationalities, associated political logics, and corroborating cultural sensibilities (Williams, Davies “The Limits of Neoliberalism”). In concert, these constitutive elements of the neoliberal condition have redefined-amongst other things-the contract between the contemporary state and its citizens, and, crucially, the understanding of nature and role of individual citizens living within the neoliberal state (Hall "The Neoliberal Revolution"). As Rottenburg neatly summarized: “Neoliberalism, in other words, is a dominant political rationality that moves to and from the management of the state to the inner workings of the subject, normatively constructing and interpellating individuals as entrepreneurial actors” (420). Of course, neoliberal policies or initiatives are rarely, if indeed ever, signposted as such. Rather, such is the nature of the neoliberal hegemony functioning within contemporary democratic societies, neoliberalism exists and operates at the virtually 
subliminal level of the taken-for-granted or common sense (Hall and O’Shea). Pace Monbiot, is it any wonder, therefore, why we struggle to define or even recognize it?

In order to begin to attend to Monbiot's neoliberal conundrum, we turn to Raymond Williams' understanding of a "structure of feeling": those contingent "characteristic elements of impulse, restraint, and tone” that constitute a pattern of common experiences, perceptions, and affective responses-identifiable within, and across, cultural forms-which speak to the contingent forces and relations operating within a given moment (Williams 132). Apply Williams' theorizing to the neoliberal present, McGuigan (23) continued, "The neoliberal structure of feeling is not just a matter of ideas and emotions. It is inscribed into habitual modes of conduct and routine practices governing everyday life in a largely unexamined and semi-conscious manner.” So, the pervasiveness and the invasiveness of neoliberalism as a structure of feeling has contributed to the semi-conscious encroachment of particular values, strategies, and outcomes into the nature and experience of everyday life. The latter includes the focus of this discussion: the highly commercialized and spectacularized domain of elite and professional sport, sometimes referred to as corporate sport (Andrews "Sport-Commerce-Culture"). For, as we hope to explicate within this analysis, sport is an important part of contemporary popular culture, through which neoliberal structures of feeling-and hence, the neoliberal project more broadly-become enthusiastically experienced and normalized by the sport consuming masses. Corporate sport culture may not be explicitly political (other than obligatory expressions of nationalism and/or militarism as part of the sport spectacle). However, it is our contention that it is implicitly politicized: it has been articulated to, and simultaneously articulates neoliberal sensibilities, in such a way that covertly reproduces the neoliberal order through the seeming benign experience 
of sport consumption. It is for this reason that Monbiot, quite rightly in our viewpoint, highlighted the invasiveness yet abstruseness of neoliberalism: it is a hegemonic political project (or perhaps more accurately, sensibility) that is lived, felt, yet all too rarely considered.

Updating Williams' notion of the structure of feeling, Gilbert ("Anticapitalism and Culture" 90) suggested the term “affective regime” as a descriptor of the terrain upon which contemporary populist politics is waged. Grossberg's ("We Gotta Get out of This Place") notion of “affective epidemic” is equally instructive in this regard. Whichever one chooses is immaterial, since both point to the ability of hegemonic political formations to co-opt popular cultural practices, including sport, and render them sites for the expressive re-enactment of normalized, highly politicized, affective investments. With regards to neoliberal politics, this is process is characterized by, amongst other things, positive affective orientations toward the nation, the free market, and expressions of individualism; and, negative affective orientations toward the State, public institutions, and expressions of non-majority collectivism (Anderson). As Hall and O'Shea identified, the disjunctive-and at times contradictory-nature of this compendium of neoliberal “common-sense” is attenuated by its affective dispositions, which provide a sense of intuitive coherence guiding one's experience of the world. Not that such hegemonic affective orientations are somehow post-ideological, despite being experienced as such. Rather, normalized affective investments in popular cultural forms and practices-such as sport-tend to veil the ideological assumptions with which they are inextricably bound [Grossberg "Cultural Studies: What's in a Name?”, Mellencamp]. 
Written from a largely U.S. perspective (although informed by other variants of neoliberalism and corporate sport), within the following discussion, we intend to illustrate how contemporary popular sport culture is articulated to and through (Slack), and thereby normalizes, the affectiveideological presumptions of the prevailing neoliberal consensus. For us, sport is one of a "range of significant cultural phenomena”...that..."share and work to reproduce the basic presuppositions of neoliberal thought and the long-term social objectives of neoliberal policy" (Gilbert "What Kind of Thing Is Neoliberalism?" 12). Hence, our aim is to excavate the neoliberal nature, and neoliberalizing function, of corporate sport. In doing so, we hope to demonstrate some of the ways corporate sport acts an affect orienting agent of neoliberal public pedagogy, that further popularizes-if in a semi-conscious manner-neoliberal maxims, subjects, and psyches (Newman and Giardina).

\section{Corporate Sport and Neoliberalism as Abstract Machines}

To anyone interested in the critical analysis of popular culture, sport's co-optation by the hegemonic neoliberal project should come as no surprise. As Hall famously noted, "there is no whole, authentic, autonomous 'popular culture' which lies outside the field of force of the relations of cultural power and domination"(Hall "Notes on Deconstructing "the Popular" 232). From a cultural materialist perspective, sport-as with any other form of popular culture-is a “"a a rich aggregate of many determinations and relations” (Marx, as cited inMcLellan 351) that simply cannot "exist apart from the forces of the context that constitute it as what it is" (Grossberg "Cultural Studies: What's in a Name?" 255). Since we are ensconced within a moment of normalized neoliberalism, there is little alternative but for popular cultural practices 
and events to become sutured to the "basic presuppositions of neoliberal thought" (Gilbert "What Kind of Thing Is Neoliberalism?" 12). Nonetheless, it would be remiss to assert some blanket neoliberalization of contemporary sport culture. The politicization of popular culture simply does not operate in such a uniform manner. Rather, and like the manifestations of neoliberalism more broadly (Ong), the neoliberalization of sport renders it a complex, socio-spatially contingent, and, at times, contradictory technology of governance. In this vein, it is instructive to turn to Gilbert’s ("What Kind of Thing Is Neoliberalism?") suggestive utilization of Deleuze and Guattari’s theorising in understanding of neoliberalism as an "abstract machine:

Using a term of Deleuze and Guattari's, we might describe neoliberalism as a name for the 'abstract machine' of post-Fordist capitalism. An abstract machine is a functional diagram of the forces animating a concrete assemblage. Conceiving neoliberalism as an abstract machine allows us to avoid any charge of ignoring the unevenness and relative failures of the various policies and programmes which are generally grouped together under that name, perhaps even better than does conceiving it as a hegemonic project. Neoliberalism does not manifest itself everywhere in the same way, or anywhere in it absolutely pure form. Nonetheless, it has a discernible identity precisely by virtue of the similarity of the operations which it attempts across a range of spheres which offer varying degrees of resistance to its 'cutting edges'. (Gilbert 174 italics added)

Through reference to neoliberalism as abstract machine, Gilbert provides a framework for understanding the (non-necessary) uniformity of neoliberalism as articulated to, and through, various aspects of contemporary culture, including sport. Differently put, the various affective commitments associated with neoliberalism are experienced at a "certain level of abstraction" 
which ascribes it (neoliberalism) a sense of coherence and consistency not necessarily manifest in all of "concrete instantiations" (Gilbert "What Kind of Thing Is Neoliberalism?"21), sporting or otherwise. Similarly, contemporary corporate sport's relationship to the abstract machine of neoliberalism is uneven and, at times, inconsistent. Nonetheless, the cultural weight of normalized neoliberalism's forces and vectors of effect act upon sport, in a manner that disarmsby rendering inconsequential-any neoliberal contradictions or inconsistencies evident within the sporting landscape.

Corporate sport could itself be described as an abstract machine. It is a functional model of the hegemonic sport formation that bears the indelible imprint of contemporary late capitalism (Jameson "Postmodernism","The Cultural Turn"): specifically, the conjoined processes pertaining to the commercialization of culture and culturalization of the economy (Andrews "Sport-Commerce-Culture"). As an abstract machine of late capitalism, corporate sport (typified by the institutionalization, bureaucratization, commercialization, and spectacularization of elite sport as a mass entertainment product designed to generate maximum surplus value across myriad revenue streams), is now the accepted structural and ideological blueprint for commercial sport organizations (McKay and Miller; Walsh and Giulianotti):

Today, virtually all aspects of the global sport institutions (governing bodies, leagues, teams, events, and individual athletes) are now un-selfconsciously driven and defined by the inter-related processes of: corporatization (the management and marketing of sporting entities according to profit motives); spectacularization (the primacy of producing of 
entertainment-driven [mediated] experiences); and, commodification (the generation of multiple sport-related revenue streams). (Andrews and Ritzer 140)

Despite this, and once again invoking Gilbert ("What Kind of Thing Is Neoliberalism?" 21), the machinic nature of corporate sport does not result in it being manifest "everywhere in the same way, or anywhere in it absolutely pure form.” Corporate sport is a variegated phenomenon, whose precise manifestation is dependent upon the contingent forces and relations of the context in question. As with the process of neoliberalization, so corporate sport can be "highly variegated in its features, impact and outcomes" (Fine and Saad-Filho 11, italics in original). Indeed, even sports located within the same setting are oftentimes corporatized in markedly different ways, even if such variations become obfuscated by the functional diagrammatic of corporate sport as abstract machine.

While the corporate commercialization of sport long pre-dated the prevalence of neoliberalism's ideological and affective norms, the coexistence of these two abstract machines (neoliberalism and corporate sport) resulted in their unavoidable mutual implication, and convergence. Corporate sport thus became modulated through the neoliberal abstract machine, and an exemplar of how "pre-existing technologies and cultural practices have been enlisted in the service of the process of neoliberalisation” (Hayward 270). Manufactured by the various interlocking armatures of the contemporary culture industries, high profile sport spectacles are the centrifugal force of corporate sport: their cultural, economic, and indeed political influence emanates to the constituent elements of the complex corporate sport assemblage. These sport spectacles are not produced as political functionaries per se, rather they become politicized (agents of political conformity) through their conspicuous appealing to the populist sensibilities thought necessary to generate a mass audience. The populist dictates of the contemporary 
culture industries-preoccupied with the desire to produce texts that resonate with, as opposed to controvert, mainstream views and values-generate popular representations of the sporting world that incorporate and covertly normalize key elements of the neoliberal agenda. Hence, both the sport spectacle in toto, and its composite sub-strands (the performative, embodied, promotional, pernicious, delivery, spatial, ceremonial, and social spectacles) are efficient propagators of the prevailing neoliberal consensus (Andrews "Sport, Spectacle, and the Politics of Late Capitalism"). In Hall’s terms, the late capitalist sport spectacle thus represents a form of “canned and neutralised demotic populism” ("Notes on Deconstructing "the Popular"'" 233) that covertly seduces the consuming audience to the neoliberal state of play in political, economic, and social relations. As such, and as we hope to explicate within the following sections, corporate sport became a subliminal paean to the prevailing neoliberal order.

\section{Neoliberal Economics of Corporate Sport}

Although it should never be reduced to being its sole excrescence, arguably neoliberalism's most discernible ideas and institutions are arguably economic in form and function. Percolating over a number of decades following the end of the second World War-and informed by the pronouncements of Chicago School economists (including Ludwig von Mises, Frederich Hayek, George Stigler, and Milton Friedman) and other members of the Mont Pelerin Society (Mirowski and Piehwe; Peck)-by the beginning of the 1970s, an emergent neoliberal economic orthodoxy came to challenge the social welfare consensus that dominated the political economies of many

Western democracies in the immediate post-war world. Thus ensued the "great reversal" (Palley 6), wherein the Keynesian demand-side and socially redistributive economic approach was 
systematically dismantled, and subsequently replaced, by a monetarist supply-side approach, focused on stimulating the money supply within the economy. This neoliberal economic revolution (Robison) was forged by ideas pertaining to the advantages, in countering the perceived excesses and inefficiencies of Keynesian interventionism, accrued by cultivating a largely unregulated (ideally self-regulating) and highly competitive economy. This thinking rested on the notion that the nurturing of free trade, and a concomitantly competitive market, would lead to greater economic efficiencies and innovations, and the consequent stimulation of the money supply within the economy (the money supply previously drained by the perceived excesses of Keynesian demand-side redistributive investments). Continuous increases in productivity should, according to trickle down neoliberal economic theory, deliver higher living standards to everyone-from the thriving corporate capitalist to the manual worker now in full employment-meaning that the elimination of poverty can best be secured through the establishment and protection of free markets and free trade (Harvey "A Brief History of Neoliberalism" 64-65).

According to neoliberal doctrine, for the benefit of the greater good, private corporations should be encouraged to compete within a putatively unregulated marketplace in a manner that ensures the structural rationality of the economy: productive, efficient, and profitable corporations thrive, while unproductive, inefficient, ad unprofitable corporations fall by the wayside. Given these assumptions, it is wholly understanding why neoliberal states should actively nurture a legal, regulatory, and economic climate conducive to the interests of private corporate capital. Measures such as individual and corporate tax concessions, property and development tax initiatives, and financial industry deregulation-in addition to the concerted dismantling of labour 
unions-all combined to create the type of "business-friendly climate" exalted by monetarists (Brodie 56). Within such a climate, the for-profit corporation (either privately or shareholder owned) took on a defining and determining role within the neoliberal economy. It is the "stateendorsed norm" of neoliberal institutional organization that simultaneously normalizes "marketbased principles and techniques of evaluation" throughout society as a whole (Davies "The Limits of Neoliberalism” 6). Hence, the neoliberalization of society could be said to be coterminous with its conclusive corporatization: the intensifying suffusion of the privatelyowned corporate model and profit-driven rational efficiencies across all sectors of society, including public service sector institutions that previously operated somewhat removed from commercial exigencies, (i.e. schools, universities, museums, libraries, hospitals, sanitation services, the police, and even the military). As Fisher (22) noted, invoking Deleuze's understanding of the”new" control societies, "all institutions are embedded in a dispersed corporation.” Or, in Deleuze’s $(5,7)$ terms, "the corporation, the educational system, the armed services being metastable states coexisting in one and the same modulation, like a universal system of deformation.” The universal deformed modulation being that of the corporation: the "new system of domination."

As an abstract machine, contemporary corporate sport would appear to evince Deleuze's notion of the corporation as the axial formation within a pervasive and invasive system of (neoliberal) social control. The magnifying (in scale and scope) corporatization associated with the dominant neoliberal order is certainly evidenced within the realm of professional and/or elite sport: understandably given that popular cultural forms, such as sport, are intrinsically linked to the contextual forces and relations into "which it is incorporated, the practices with which it 
articulates and is made to resonate" (Hall "Notes on Deconstructing "the Popular"' 235). Corporate sport formations unselfconsciously acknowledge their corporatized institutional structure, management hierarchies, profit-driven focus, and economically-driven rational efficiency. Moreover, the sport industry has become a self-sustaining and regulating phenomenon, constituted by undergraduate and graduate programs, professional conferences and organizations, and a thriving publications sector, all of which reproduce what are tantamount to neoliberal corporate sport orthodoxies (Newman). Even the Olympic Games, not so long ago the heavily guarded (if covertly compromised) bastion of athletic amateurism has become transformed by the influence of neoliberal corporatism (Boykoff "Celebration Capitalism and the Olympic Games"). Nowhere was this made more apparent than at the main entrance to the London 2012 Olympic Park (reached following a guided passage through the Westfield Stratford City shopping centre, the largest of its kind in Europe). Upon entering the Olympic Park, the expectant spectator was confronted with a massive advertising billboard, one side of which read: "There would be no: GOOSEBUMPS, GASPS, POUNDING HEARTS, TEARS OF JOY, RECORDS SMASHED, STRANGERS HUGGED, OR A WHOLE WORLD BROUGHT TOGETHER. without...” Panning to the right, the other side of the billboard identified those to whom we should apparently be grateful for the staging of the visceral and exhilarating Olympic spectacle: the myriad Olympic corporate sponsors, including Coca-Cola, Dow, GE, McDonalds, Panasonic, Samsung, and Visa. Given the Olympics spectator's immediate experience of the event, one commentator characterized London 2012 as 'a strange new hybrid of sports appreciation and consumerism gone wild. Or worse, the Mall Olympics” (Segal). 
Of course, the commercial corporatization of sport pre-dated the, ultimately successful, struggle for a neoliberal corporatist hegemony which commenced in the early 1980s (see Gorn and Goldstein; Hardy). Nonetheless, contemporary late capitalist corporate sport has reached an precedented level of private commercialization and popular acceptance, such that, it has become a normalized and normalizing agent of society's overarching economic neoliberalization. We are conditioned to expect the malling of the Olympics, and not to disavow it. In Fukuyama's (3) oft-repeated terms, the infusion of corporate sport model into the hearts and minds of both sport produces and consumers alike, means there has been a "total exhaustion of viable systematic alternatives." The corporate sport model has thus become an expression, and reproducer of neoliberal “common-sense” [Hall and O’Shea “Common-Sense”); a popular cultural form surreptitiously guiding and shaping the understanding, feelings, and experience, of the neoliberal world.

\section{Spaces of Actually Existing Sporting Neoliberalism}

According to numerous commentators (Coakley, Hall, Hartmann, King, Schimmel), contemporary sport culture acts-through myriad institutions, intermediaries, and agents (both of the playing and non-playing varieties) as key sites of public pedagogy-to reinscribe, represent, and effectively reproduce the hegemonic practices, values, and affective orientations of the neoliberal moment. It is for this reason we assert that the corporatization of sport is coterminous with its neoliberalization. Hence, in this section we engage corporate sport as an examples of what Brenner and Theodore referred to as "actually existing neoliberalism": the ongoing process of neoliberalization manifest within specific sporting sites. Brenner and Theodore’s (351) approach is particularly apropos for our analysis, since they focused on the "role of urban spaces 
within the contradictory and chronically unstable geographies of actually existing neoliberalism.” Similarly, our focus is on the position and role of elite/professional sport events in the realization of spatially-bound neoliberal development initiatives.

Within many developed economies (and for various reasons, not least of which being the compounding factors of deindustrialization, suburbanization, decreasing tax bases, and diminishing state and federal support), entrepreneurial (neoliberal) approaches to urban economic development have largely replaced managerial (social welfare) commitments to serving a cities population (Harvey "Spaces of Capital"; Peck and Tickell). In short, within the neoliberal conjuncture, the city and its various resources (spaces, attributes, services, and populace) are engaged as potential motors of economic growth, as opposed to sites requiring significant levels of public investment. Accordingly, entrepreneurial urban governance regimes develop strategies, and redirect public resources, toward redeveloping the city as a space of capital accumulation, by supporting the building of consumption-generating retail, festival, leisure, hotel, heritage, and sport spaces (Silk). The rationale behind the shift from managerial to entrepreneurial governance is rooted in core neoliberal assumptions regarding the direction of travel of the capital accumulated within these commercial spaces. The widely anticipated, and much vaunted, trickle-down of capital to city residents (in the form of expanded employment opportunities), and to city government (in the form of increased commercial tax revenues)-and the concomitant bolstering of city finances, provision for public services, and hence the quality of life within a neoliberalized city-is regularly used to justify embedding the "the logics, threads, and assumptions of capital accumulation more deeply than ever in the urban landscape” (Smith xxi). Certainly, this has been the case with the neoliberal appropriation of sport 
spectacles as a mechanism for abetting capital accumulation within the contemporary city (Boykoff "Celebration Capitalism and the Olympic Games").

Arguably the most high profile manifestations of actual existing sporting neoliberalism (though the same neoliberal logics are discernible lower down the sporting food chain, with regards to the hosting of smaller events, building of sport stadia, or the pursuit of professional sport franchises), are global sporting mega-events such as the FIFA World Cup and Olympic Games, which have become co-opted into the urban/regional/national development strategies of many places around the world (C. M. Hall). Boykoff ("Celebration Capitalism and the Sochi 2014 Winter Olympics", Celebration Capitalism and the Olympic Games") describes the Olympic Games as an expression of celebration capitalism: a regime of capital accumulation which looks to harness the "feel good factor" (Grix and Houlihan) associated with hosting the event, to guide the affective orientation of the general public toward the bidding for the event and, if successful, its eventual hosting. Much of this affective politics keys on the multifarious benefits that are widely trumpeted as accruing to a host city/region/nation (these include stimulating: sport participation; tourism; consumption; job creation; and urban development), regardless of whether there is solid empirical evidence supporting any such claims (Coates and Humphreys, Weed et al.). For instance, Sir Digby Jones, head of the Confederation of British Industry, enthused on the occasion of London securing the bid for the 2012 games:

This is fabulous news for everyone in the UK. The best bid won and now it is up to us all to make a reality of the dream. Sport is big business and the Olympic Games will be a win-win for the economy and sporting competition. The Games will lift our international 
profile, attract inward investment and boost profits and jobs for everyone. They will help raise our competitive game around the world, and highlight to young people the fantastic rewards and exhilaration of competition. (quoted in Boykoff "Celebration Capitalism and the Olympic Games" 2).

Doubtless speaking to the exhilaration of sporting competition, Jones's words simultaneously lauded the familiar neoliberal economic mantra regarding the the trickle-down economic benefits that the host nation can expect to experience. In a similar, if more measured vein, Jerome Frost, director of Arup (a leading global engineering, design, and planning firm, and contracted to prepare the infrastucture for the Tokyo 2020 Olympic Games) advanced:

Through our experience in preparing cities [including Beijing 2008 and London 2012] for the Olympics and other international events, the firm has been responsible for much of the urban renewal of the host cities, ensuring the events serve as a catalyst for long-term investment and development. (Hayman)

Highlighting one of the core contradictions of neoliberal economics in its most developed democratic economy variant (Davies “The Limits of Neoliberalism”, Fine and Saad-Filho), these sport-focused development initiatives routinely pivot on the establishment of public-private partnerships (PPP), whereby public funds are used (either directly in terms of investment in building facilities and infrastructure etc., or indirectly through various tax-breaks or real estate incentives) to fund the structure and delivery of the event (Long). This approach reveals neoliberalism to be a less intractable project than it is sometimes positioned. PPPs, by their very 
nature, represent a collusion between public and private interests, so neoliberalism is not solely a privatized and privatizing project. Rather, public revenues often play a key role in neoliberal strategies, as long as they are used to create business (private capital) friendly conditions. PPPs are key aspects of neoliberal urban development strategies, since they offer private investors relative low risk (in terms of reduced capital outlays) for potential high rewards (Brenner and Theodore; Harvey "Spaces of Capital"). However, such partnerships are also potentially contentious as the scale of investment required means they almost unavoidably lead to the redirection of sizeable amounts of public monies away from essential public services (i.e. education, library, recreation, policing, and sanitation). As Boykoff so neatly summarised, "these public-private partnership are lop-sided: the public pays and the private profits. In a smileyfaced bait and switch, the public takes the risks and private groups scoop up the reward" ("Celebration Capitalism and the Olympic Games" 3).

While we have only been able to touch upon this issue, it is our assertion that the drive to secure high-profile sporting spaces (major events, stadia, franchises) as part of contemporary urban development initiatives, further advances the neoliberal primacies of the private sector and free market as normalized means of realizing efficient, and effective, strategies of urban governance (Silk and Andrews). Albeit with differing theoretical emphases, Zirin and Boykoff (Celebration Capitalism and the Olympic Games) moreover illustrate how the cooptation of mega-sport events by neoliberal development initiatives creates a space of sporting exception, justifying the imposition of a tranche of neoliberal policies and initiatives (i.e. the retrenchment of public service provision for underserved populations; lessening the individual and corporate tax burden and hence reducing the tax base; compulsory purchasing strategically located properties; and, 
imposing policing initiatives designed to socially cleanse key consumption spaces (Henry A. Giroux)) on the basis of their necessity for delivering conditions conducive to the the successful delivery of the sport mega-event. Hence, both directly and indirectly-and whether the sport consumer is aware of it or not, or in any way troubled by it or not-the very act of mega-event spectatorship or viewership, implicates them in the complex and convergent machinic systems of corporate sport and neoliberalism. As the intended subject of such initiatives, the sport consumer's investment in the sporting mega-event is tantamount to an affective-ideological endorsement, and further normalization, of the prevailing neoliberal order.

\section{Sporting Individualism as Inescapable Neoliberalism}

Neoliberalism can be considered both a macro political and micro political formation. In terms of the former, its mythos foregrounds the role of state in encouraging the creation of an unregulated and privatized free market. Therein, corporation's are forced compete to be productive, efficient, and profitable in order that there are in a position to flourish, and, by doing, so ensure growth within the economy more generally (Steger and Roy). With regards, to the later, neoliberalism is simultaneously a political rationality that operates at the level of the individual human agent. As much a political technology for governing economic institutions, neoliberalism operates as a mechanism for constituting and disciplining economic actors: it is "not just a manner of governing states or economies, but is intimately tied to the government of the individual” (Read 27). The cultivation of a competitive individualism is evidently a core dimension of the neoliberal project. In the terms of the enduringly influential Ayn Rand (Biressi and Nunn)-and for the necessity of developing a productive society-the neoliberal individual, 
like the neoliberal corporation, is expected to exhibit a "rational egoism" or selfishness (Rand), the central preoccupation of which being the cultivation of the self, and individual self-interest, as the primary determinant of social and economic advancement. Neoliberalism's idealized individual is thus an "entrepreneur of the self" (Foucault): a competitive, determined, responsible, and rational individual driven to maximize neoliberalism's increased freedoms (realised through reduced personal tax burdens) and opportunities (offered by the expanding privatized marketplace) in crafting individual life experiences and outcomes). Moreover, since individual lives are now crafted through an array of individualized market offerings, opportunities, and solutions, an inability to provide sufficiently for ones "own needs...and ambitions” becomes a marker of a lack of moral responsibility, or a sign of pathological inferiority, rather than a statement on the structural inadequacies or inequalities implicit within the social formation (Brown 694). Hence, through the normative construction and interpellation of individual subjects as entrepreneurial actors (Rottenberg), the neoliberalism governs, or responsibilitizes, the individual "to a particular manner of living” (Read 27).

As a spectacle pitting individuals, or collections of individuals, against each other in contestbased, zero-sum, and highly-competitive physical performances it is clear to see how, within a political conjuncture steeped in the normalized notions of competitive individualism, sport is an almost unavoidable emissary of neoliberal common-sense. Neoliberal thinking rests on the the notion of a neoliberalized society as being a meritocracy (an egalitarian social formation in which individuals achieve, solely due to a combination of ability and effort) (Littler). So, the pervasive myth of elite sport as a meritocracy (a playing field in which only the most able, strongest, and most determined succeed) (Newman and Falcous) nurtures, as it further 
normalizes, neoliberalism's discourse of competitive individualism. Elite athletes are routinely constituted as popular subjects through the output of the populist media, through being articulated as the ultimate entrepreneurs of the self. Their celebrated persona literally come to embody the competitiveness, determination, responsibility, and rationality underpinning neoliberalism's base individualism, as they are lauded for reaping their just rewards in the form of success on the playing field, and (oftentimes) bounteous wealth off it.

The default mode within the sport media in general (Farred; Giardina and Cole; McDonald; Miller), nevertheless nowhere is the neoliberalization/competitive individualization of elite athletes better illustrated than in popular representations of superstar African American athletes. The intertextually constituted, and commercially expedient, public personas of contemporary figures such as LeBron James, Carmelo Anthony, Serena Williams, and, of course, the enduring specter of Michael Jordan (Carrington; Colás; Leonard; Spencer), have all become incorporated by neoliberalism's ideological and affective orientations, such that they are compelling agents of the America’s racialized neoliberalism (Goldberg). According to Roberts and Mahtani (254), race is an 'organizing principle of society that neoliberalism reinforces and modifies.” Perhaps more accurately, under the influence of its all-consuming individualism, neoliberalism exhibits a “tendency to potentiate individuals qua individuals while simultaneously inhibiting the emergence of all forms of potent collectivity" (Gilbert "What Kind of Thing Is Neoliberalism?" 21). Within America's neoliberal racial formation, race is simultaneously renounced and reinforced as a politically prescient category: 
Within this potential erasure neoliberalism plays a perverted race card, in that by rejecting race, formerly racialized “others” can be fully incorporated as consumptive citizens with no racial barriers to their participation in the economy. Neoliberalism, then, willfully misconstrues and dismisses the reality of racism as a powerful explanatory factor in analyzing persistent racial inequities. (Davis 354)

Highly successful, and high profile, African American athletes are thus captured by the mainstreaming popular culture industries-and through myriad strands of intertextual promotional and presentational discourse-cast to the consuming public as idealized raced neoliberal subjects; their very success disavowing the continued existence, and hence pointing to the irrelevance, of race and racial difference. The carefully managed marketized identities of prominent Black athletes are thus made to resonate with neoliberalism's colour-blind ethos which, neuters racial difference as a political, if not an aesthetic, category (Bonilla-Silva, Gallagher). Through the widespread promotion of their non-normative raced persona, these celebrated Black athletes become discursive figures against which demonized notions of the black populace (as being nonproductive, pathologically degenerate, and/or disposable) are constructed, and effectively normalized (H.A. Giroux). These athletes carefully-choreographed racial atypicality thus essentialized urban black populations and cultures; casting them as effects of a pathological indolence and criminality, as opposed to being a response to historically wrought and systemic forms of race-based discrimination (Andrews and Mower; Andrews, Mower and Silk).

Celebrated athletes such as James, Anthony, Williams, and Jordan, thus act as persuasive public pedagogues, becoming seductive agents of neoliberal micro-governance which idealize particular ways of being in the world, while demonizing others. Such populist strategies of public 
representation naturalizes and normalizes neoliberal agendas and ideologies, allowing them to stealthily inhabit popular consciousness, and bolster popular affective investments in, amongst other things, common-sense neoliberal notions competitive individualism. Hence, the (raciallycoded) neoliberalized athlete becomes a compelling, if covert, agent in normalizing, the affective-ideological presumptions of the prevailing neoliberal consensus.

\section{Conclusion: Sporting (Dis)Affections?}

On July 28, the bid to bring the summer Olympics to Boston was laid to rest...the public pressure and opposition to the neoliberal and gentrification plans of big developers and the United States Olympic Committee (USOC) triumphed! Boston joins a growing list of cities such as Munich, Oslo, and Stockholm that have rejected bids for the Olympics. These victories show that it is possible to push neoliberalism back and can give strength to other cities in the U.S. and around the world. (Moxley)

Within this discussion, we have outlined an approach to the understanding of corporate sport as a vehicle through which the neoliberal structure of feeling becomes inscribed into everyday conduct and consciousness (McGuigan). However, the interpellation of individual subjects is far from guaranteed. Writing in Socialist Alternative, Moxley described the defeat of Boston’s bid for the 2024 Summer Olympic Games as an example of “working people’s victory over neoliberalism", and pointed to Boston being the latest in a "growing list of cities such as Munich, Oslo, and Stockholm that have rejected bids for the Olympics” (a list to which Budapest can be 
added, as the latest city to reject bidding for the Olympic circus). Moxley concluded, 'This fightback is an inspiration to all who want to organize against neoliberalism and gentrification, and all who want sports games for the people, not for profit”. Although the most prominent, sport mega-events such as the Olympics and FIFA World Cup are by no means the sole sporting targets for anti-neoliberal sentiment and activism (Boykoff, "Celebration Capitalism and the Olympic Games”; Gaffney ; Horne, 2015; Lauermann, 2016]. Webber outlined the amorphous, yet discernible, “Against Modern Football” movement, of which the FC Sankt Paul fan organization examined by Totten is a noted exemplar. In addition, Scherer highlighted grassroots community opposition to the use of public funds to finance the building of an ice hockey arena and entertainment district in Edmonton, Canada.

The opposition to sporting neoliberalism is by no means surprising, since the power and authority of any hegemonic formation incorporates, within its very ascendancy, it creates the conditions of existence for its own potential opposition (Williams). Nevertheless, we contend that the mutually reinforcing neoliberal and corporate sport hegemonies defuse any meaningful opposition to their respective positions of authority. Activist movements periodically agitate against both neoliberalism in general, and its corporate sport offspring, yet both abstract machines plough on largely unaffected. So, despite examples of evident disaffection with various actually existing/actively proposed sporting neoliberalisms, we contend that corporate sport in general continues to act as a covert corroborator of neoliberalism's privatizing, marketizing, and individualizing logics. As an armature and outgrowth of neoliberal states preoccupied with market structures, forces, and outcomes (Davies "When is a market not a market"), the constituent components of corporate sport effectively normalize, as they guide, 
popular affective investment in the belief system underpinning common-sense neoliberalism (Hall and O’Shea). So, while, as a popular cultural practice, sport is always already politicized, corporate sport is inextricably neoliberalized and neoliberalizing. Somehow rooting for the home team, has never seemed less appealing.

\section{Works Cited}

Anderson, B. "Neoliberal Affects." Progress in Human Geography 40.6 (2015): 734-53. Print. Andrews, D.L. Sport-Commerce-Culture: Essays on Sport in Late Capitalist America. New York: Peter Lang, 2006. Print.

---. "Sport, Spectacle, and the Politics of Late Capitalism: Articulating the Neoliberal Order." The Handbook of Sport and Politics. Eds. Bairner, A.S., J. Kelly and J.W. Lee. London: Routledge, 2017. Print.

Andrews, D.L., R.L. Mower, and M.L. Silk. "Ghettocentrism and the Essentialized Black Male Athlete." Commodified and Criminalized: New Racisms and African Americans in Contemporary Sports. Eds. Leonard, D.J. and C.R. King. Lanham, MD: Rowman \& Littlefield, 2011. 69-94. Print.

Andrews, David L., and Ron L. Mower. "Spectres of Jordan." Ethnic and Racial Studies 35.6 (2012): 1059-77. Print.

Andrews, David L., and George Ritzer. "The Grobal in the Sporting Glocal." Global Networks 7.2 (2007): 135-53. Print.

Biressi, Anita, and Heather Nunn. "Selfishness in Austerity Times." Soundings: A journal of politics and culture 56.Spring (2014): 54-66. Print. 
Bonilla-Silva, E. Racism without Racists: Color-Blind Racism and the Persistence of Racial Inequality in the United States. Second ed. Lanham, MD: Rowman \& Littlefield, 2006. Print.

Bourdieu, P., and L. Wacquant. "Neoliberal Speak: Notes on the New Planetary Vulgate." Radical Philosophy.105 (2001): 2-5. Print.

Boykoff, J. Celebration Capitalism and the Olympic Games. London: Routledge, 2014. Print.

---. "Celebration Capitalism and the Sochi 2014 Winter Olympics." Olympika: The International Journal of Olympic Studies XXII (2013): 39-70. Print.

Brenner, N., and N. Theodore. "Cities and the Geographies of “Actually Existing Neoliberalism”." Antipode 34.3 (2002): 349-79. Print.

Brodie, J. "Income Inequality and the Future of Global Governance." Critical Perspectives on the Crisis of Global Governance: Reimagining the Future. Ed. Gill, S. Basingstoke: Palgrave Macmillan, 2015. 45-68. Print.

Brown, W. "American Nightmare: Neoliberalism, Neoconservatism, and De-Democratization." Political Theory 34.6 (2006): 690-714. Print.

Carrington, B. Race, Sport and Politics: The Sporting Black Diaspora. London: Sage, 2010. Print.

Coakley, J. "Ideology Just Doesn't Happen: Sports and Neoliberalism." Journal of ALESDE 1.1 (2011): 67-84. Print.

Coates, D., and B. Humphreys. "Do Economists Reach a Conclusion on Subsidies for Sport Franchises, Stadiums, and Mega-Events?’." Economic Journal Watch 5.3 (2008): 294315. Print. 
Colás, Santiago. Ball Don't Lie!: Myth, Genealogy, and Invention in the Cultures of Basketball. 2016. Philadelphia: Temple University Press. Print

Davies, W. "When Is a Market Not a Market?: ‘Exemption’, ‘Externality’ and 'Exception’ in the Case of European State Aid Rules." Theory, Culture \& Society 30.2 (2013): 32-59. Print.

Davies, W. The Limits of Neoliberalism: Authority, Sovereignty and the Logic of Competition. 1 online resource (xiii, 220 pages) vols. London : SAGE, 2014. Print.

Davis, D-A. "Narrating the Mute: Racializing and Racism in a Neoliberal Moment." Souls: A Critical Journal of Black Politics, Culture, and Society 9.4 (2007): 346-60. Print.

Deleuze, G. "Postscript on the Societies of Control." October 59.Winter (1992): 3-7. Print. Farred, G. "The Uncanny of Olympic Time: Michael Phelps and the End of Neoliberalism." Sport and Neoliberalism: Politics, Consumption, and Culture. Eds. Andrews, D.L. and M.L. Silk. Philadelphia: Temple University Press, 2012. 109-23. Print.

Fine, B., and A. Saad-Filho. "Thirteen Things You Need to Know About Neoliberalism." Cultural Sociology (2016). Print.

Fisher, M. Capitalist Realism: Is There No Alternative? Winchester, UK/Washington, DC: Zero Books, 2009. Print.

Foucault, M. The Birth of Biopolitics: Lectures at the College De France, 1978-1979. New York: Picador, 2010. Print.

Fukuyama, F. "The End of History?" The National Interest 16 (1989): 3-18. Print.

Gaffney, C. "An Anatomy of Resistance: The Popular Committees of the Fifa World Cup in Brazil." Sport, Protest and Globalisation: Stopping Play. Eds. Dart, Jon and Stephen Wagg. London: Palgrave Macmillan, 2016. 335-64. Print. 
Gallagher, C.A. "Color-Blind Privilege: The Social and Political Functions of Erasing the Color Line in Post Race America." Race, Gender \& Class 10.4 (2003): 22-37. Print.

Giardina, M., and C.L. Cole. "Race, Class, and Politics in Post-Katrina America." Sport and Neoliberalism: Politics, Consumption, and Culture. Eds. Andrews, D.L. and M.L. Silk. Philadelphia: Temple University Press, 2012. 57-74. Print.

Gilbert, J. "What Kind of Thing Is "Neoliberalism"?" New Formations 80.1 (2013): 7-22. Print.

---. "What Kind of Thing Is Neoliberalism?" New Formations 80-81 (2013): 7-22. Print.

Gilbert, J. Anticapitalism and Culture: Radical Theory and Popular Politics. Culture Machine Series; Culture Machine Series. Oxford: Berg, 2008. Print.

Giroux, H.A. "Beyond the Biopolitics of Disposability: Rethinking Neoliberalism in the New Gilded Age." Social Identities 14.5 (2008): 587-620. Print.

Giroux, Henry A. "Neoliberalism and the Machinery of Disposability." Dangerous Thinking in the Age of the New Authoritarianism. Boulder, CO: Paradigm Publishers, 2015. 97-107. Print.

Goldberg, D.T. The Threat of Race: Reflections on Racial Neoliberalism. Malden, MA: WileyBlackwell, 2008. Print.

Gorn, Elliott J., and Warren Goldstein. A Brief History of American Sports. 1st Ill. pbk. ed. Urbana, IL: University of Illinois Press, 2004. Print.

Grix, Jonathan, and Barrie Houlihan. "Sports Mega-Events as Part of a Nation's Soft Power Strategy: The Cases of Germany (2006) and the Uk (2012)." The British Journal of Politics \& International Relations (2013): n/a-n/a. Print.

Grossberg, L. "Cultural Studies: What's in a Name? (One More Time)." Bringing It All Back Home: Essays on Cultural Studies. Durham: Duke University Press, 1997. 245-71. Print. 
---. We Gotta Get out of This Place: Popular Conservatism and Postmodern Culture. London: Routledge, 1992. Print.

Hall, C.M. "Urban Entrepreneurship, Corporate Interests and Sports Mega-Events: The Thin Policies of Competitiveness within the Hard Outcomes of Neoliberalism." Sociological Review 54.S2 (2006): 59-70. Print.

Hall, S. "The Neoliberal Revolution." The Neoliberal Crisis. Eds. Rutherford, J. and S. Davison. London: Soundings: Lawrence Wishart, 2012. 8-26. Print.

---. "Notes on Deconstructing "the Popular"." People's History and Socialist Theory. Ed. Samuel, R. London: Routledge \& Kegan Paul, 1981. 227-40. Print.

Hall, S., and A. O’Shea. "Common-Sense Neoliberalism." After Neoliberalism: The Kilburn Manifesto. Eds. Hall, S., D. Massey and M. Rustin. London: Soundings, 2015. 52-68. Print.

Hardy, S. "'Adopted by All the Leading Clubs': Sporting Goods and the Shaping of Leisure, 1800-1900." For Fun and Profit: The Transformation of Leisure into Consumption. Ed. Butsch, R. Philadelphia: Temple University Press, 1990. 71-101. Print.

Hartmann, Douglas. Midnight Basketball: Race, Sports, and Neoliberal Social Policy. Chicago: University of Chicago Press, 2016. Print.

Harvey, D. A Brief History of Neoliberalism. Oxford: Oxford University Press, 2005. Print.

---. Spaces of Capital: Towards a Critical Geography. Edinburgh: Edinburgh University Press, 2001. Print.

Hayman, A. "Arup Wins Key Role on Tokyo Olympics." Building.co.uk (2014). Web. Hayward, M. "Atms, Tele-Prompters and Photo-Booths: A Short History of Neoliberal Optics." Neoliberal Culture. Ed. Gilbert, J. London: Lawrence \& Wishart, 2016. Print. 
Horne, John. "Sports Mega-Events - Three Sites of Contemporary Political Contestation." Sport in Society (2015): 1-13. Print.

Jameson, F. The Cultural Turn: Selected Writings on the Postmodern 1983-1998. London \& New York: Verso, 1998. Print.

---. Postmodernism, or, the Cultural Logic of Late Capitalism. Durham: Duke University Press, 1991. Print.

King, S.J. "Nike U: Full-Program Athletics Contracts and the Corporate University." Sport and Neoliberalism: Politics, Consumption, and Culture. Eds. Andrews, D.L. and M.L. Silk. Philadelphia: Temple University Press, 2012. 75-89. Print.

Lauermann, J. "Boston’s Olympic Bid and the Evolving Urban Politics of Event Led Development." Urban Geography 37.2 (2016): 313-21. Print.

Leonard, D.J. After Artest: The Nba and the Assault on Blackness. Albany, NY: State University of New York Press, 2012. Print.

Littler, J. "Meritocracy as Plutocracy: The Marketising of ‘Equality’ under Neoliberalisn." New Formations 80/81 (2013): 52-72. Print.

Long, JG. Public/Private Partnerships for Major League Sports Facilities. New York: Routledge, 2013. Print.

McDonald, M.G. "Out-of-Bounds Plays: The Women's National Basketball Association and the Neoliberal Imaginings of Sexuality." Sport and Neoliberalism: Politics, Consumption, and Culture. Eds. Andrews, D.L. and M.L. Silk. Philadelphia: Temple University Press, 2012. 211-24. Print.

McGuigan, Jim. Neoliberal Culture. New York, NY: Palgrave Macmillan, 2016. Print. 
McKay, J., and T. Miller. "From Old Boys to Men and Women of the Corporation: The Americanization and Commodification of Australian Sport." Sociology of Sport Journal 8.1 (1991): 86-94. Print.

McLellan, D. Karl Marx: Selected Writings. Oxford: Oxford University Press, 1977. Print.

Mellencamp, P. High Anxiety: Catastrophe, Scandal, Age, and Comedy Bloomington, IN: Indiana University Press, 1992. Print.

Miller, T. "A Distorted Playing Field: Neoliberalism and Sport through the Lens of Economic Citizenship." Sport and Neoliberalism: Politics, Consumption, and Culture. Eds. Andrews, D.L. and M.L. Silk. Philadelphia: Temple University Press, 2012. 23-37. Print. Mirowski, P., and D. Piehwe. The Road from Mont Pelerin: The Making of the Neoliberal Thought Collective. 2009.Web.

Monbiot, G. "Neoliberalism: The Ideology at the Root of All Our Problems." The Guardian April 15 2016, sec. Books. Print.

Moxley, A. "Boston Says No to Olympics: Working People’s Victory over Neoliberalism." Socialist Alternative (2015). Web.

Newman, J.I. "Sport without Management." Journal of Sport Management 28 (2014): 603-15. Print.

Newman, J.I., and M. Falcous. "Moorings and Movements: The Paradox of Sporting Mobilities." Sites: New Series 9.1 (2012): 38-58. Print.

Newman, J.I., and M. Giardina. Sport, Spectacle, and Nascar Nation: Consumption and the Cultural Politics of Neoliberalism. New York: Palgrave Macmillan, 2011. Print.

Ong, A. Neoliberalism as Exception: Mutations in Citizenship and Sovereignty. Durham, NC: Duke University Press, 2006. Print. 
Palley, T.I. "From Keynesianism to Neoliberalism: Shifting Paradigms." Neoliberalism - a

Critical Reader. Eds. Saad-Filho, A. and D. Johnston. London: Pluto Press, 2005. 20-29. Print.

Peck, J., and A. Tickell. "Neoliberalizing Space." Antipode 34.3 (2002): 380-404. Print.

Peck, Jamie. Constructions of Neoliberal Reason. Oxford: Oxford University Press, 2010. Print.

Rand, Ayn. The Virtue of Selfishness: A New Concept of Egoism. New York: New American Library, 1964. Print.

Read, J. "A Genealogy of Homo-Economicus: Neoliberalism and the Production of Subjectivity." Foucault Studies 6 (2009): 25-36. Print.

Roberts, David J., and Minelle Mahtani. "Neoliberalizing Race, Racing Neoliberalism: Placing "Race” in Neoliberal Discourses." Antipode 42.2 (2010): 248-57. Print.

Robison, Richard. The Neoliberal Revolution: Forging the Market State. Basingstoke: Palgrave Macmillan, 2006. Print.

Rottenberg, Catherine. "The Rise of Neoliberal Feminism." Cultural Studies 28.3 (2014): 41837. Print.

Scherer, Jay. "Resisting the World-Class City: Community Opposition and the Politics of a Local Arena Development." Sociology of Sport Journal 33.1 (2016): 39-53. Print.

Schimmel, K. "Neoliberal Redevelopment, Sport Infrastructure, and the Militarization of U.S. Urban Terrain." Sport and Neoliberalism: Politics, Consumption, and Culture. Eds. Andrews, D.L. and M.L. Silk. Philadelphia: Temple University Press, 2012. 160-76. Print. 
Segal, D. "Going to the Olympics? First Event Is Mall Walking." The New York Times (2012). Web.

Silk, M.L., and D.L. Andrews. "The Governance of the Neoliberal Sporting City." Sport and Neoliberalism: Politics, Consumption, and Culture. Eds. Andrews, D.L. and M.L. Silk. Philadelphia: Temple University Press, 2012. 127-42. Print.

Silk, Michael L. "Come Downtown \& Play." Leisure Studies 26.3 (2007): 253 - 77. Print.

Slack, J. D. "The Theory and Method of Articulation in Cultural Studies." Stuart Hall: Critical Dialogues in Cultural Studies. Eds. Morley, D. and K.H. Chen. London: Routledge, 1996. 112-27. Print.

Smith, N. "Foreword." The Urban Revolution. Ed. Lefebvre, Henri. Minneapolis :: University of Minnesota Press, 2003. vii-xxiii. Print.

Spencer, N.E. "Sister Act Vi: Venus and Serena Williams at Indian Wells: "Sincere Fictions" and White Racism." Commodified and Criminalized: New Racisms and African Americans in Contemporary Sports. Eds. Leonard, D.J. and C.R. King. Lanham, MD: Rowman \& Littlefield, 2011. 41-68. Print.

Steger, Manfred B., and Ravi K. Roy. Neoliberalism: A Very Short Introduction. 2010.Web $<$ Ebook Library

Totten, Mick. "Football and Community Empowerment: How Fc Sankt Pauli Fans Organize to Influence." Soccer \& Society (2015): 1-18. Print.

Walsh, A.J., and Richard Giulianotti. "This Sporting Mammon: A Normative Critique of the Commodification of Sport." Journal of the Philosophy of Sport XXVIII (2001): 53-77. Print. 
Webber, D. M. "'Playing on the Break: Karl Polanyi and the Double-Movement 'against Modern Football." International Review for the Sociology of Sport (2015). Print.

Weed, Mike, et al. "The Olympic Games and Raising Sport Participation: A Systematic Review of Evidence and an Interrogation of Policy for a Demonstration Effect." European Sport Management Quarterly 15.2 (2015): 195-226. Print.

Williams, R. Marxism and Literature. Oxford: Oxford University Press, 1977. Print.

Zirin, Dave. Brazil's Dance with the Devil : The World Cup, the Olympics, and the Fight for Democracy. Chicago: Haymarket Books, 2014. Print. 